\title{
External quality assessment of transporting infectious substances in Canada
}

\author{
Shelley M Tiffin ART BMLSc, Michael A Noble MD FRCPC
}

\begin{abstract}
SM Tiffin, MA Noble. External quality assessment of transporting infectious substances in Canada. Can J Infect Dis $1999 ; 10(3): 246-251$.
\end{abstract}

OBJECTIVE: To determine the degree of compliance with Transport Canada's Transportation of Dangerous Goods Regulations for transporting infectious substances in Canada.

DESIGN: A three-phase study including observation of packages arriving at the British Columbia Centre for Disease Control (BCCDC) provincial laboratory; observation of requested samples of either an Escherichia coli culture or serum, not human immunodeficiency virus (HIV) or HbsAg positive, from laboratories; and a questionnaire concerning training and certification of packers in laboratories.

RESULTS: During phase 1,500 packages arriving at the BCCDC provincial laboratory were assessed. All arrived intact, with $384(76.8 \%)$ in a firm outer package. Only $178(35.6 \%)$ contained absorbent material. Six samples were known to contain human immunodefiency virus or hepatitis B; all were appropriately packaged. Of the remainder, $11(2.2 \%)$ were considered overpackaged, $192(38.4 \%)$ acceptably packaged and $191(38.2 \%)$ inadequately packaged. In phase 2, 138 requested packages were assessed. All arrived intact, 132 (95.7\%) in a firm outer package. Ninety-six (69.6\%) contained absorbent material. Only six (4.3\%) were considered inadequately packaged. In phase 3, 171 laboratories responded to a questionnaire. Fifty-nine were from small laboratories, 53 from intermediate laboratories and 23 from large laboratories. Most laboratories (55.4\%) relied on in-house resources to train packers. Only $26(15.3 \%)$ facilities had no certified packers, and $60.8 \%$ noted they had a formal copy of the regulations available in the laboratory. Laboratory characteristics associated with the likelihood of overpackaging included number of technologists $\left({ }^{2}=5.72 ; \mathrm{P}=0.058\right)$, number of samples processed by laboratories $\left({ }^{2}=8.46 ; \mathrm{P}=0.015\right)$ and being a private laboratory as opposed to being a hospital laboratory (Fisher Exact two-tailed 0.040).

CONCLUSIONS: Canadian laboratories tend to package safely and within the acceptable range of regulation, although not within the precision of regulation. Most laboratories have trained and certified packers. The most common error is the use of outer packaging that is not firm. Larger laboratories tend to overpackage resulting in increased costs.

Key Words: Canada, Escherichia coli, External quality assessment, Transportation of dangerous goods

\section{Évaluation externe de la qualité du transport des substances infectieuses au Canada}

OBJECTIF : Déterminer le degré d'adhésion aux Règlements sur le transport des matières dangereuses de Transport Canada pour le transport de substances infectieuses.

MODÈLE : Une étude en 3 phases comprenant une observation des colis arrivant au Laboratoire provincial de lutte contre la maladie de la Colombie-Britannique; une observation des échantillons requis, soit d'une culture d'Escherichia coli, soit du sérum non infecté par le virus de l'immunodéficience humaine ou positif pour l'HbsAg, provenant des

voir page suivante

${ }^{1}$ Clinical Microbiology Proficiency Testing, Department of Pathology and Laboratory Medicine, University of British Columbia and

${ }^{2}$ Transport Canada, Pacific Region, Vancouver, British Columbia

Correspondence and reprints: Dr MA Noble, Room 328A - 2733 Heather Street, Vancouver, British Columbia V5Z 1 M9.

Telephone 604-875-4685, fax 604-875-4100, e-mail mnoble@unixg.ubc.ca

Received for publication August 11, 1998. Accepted October 5, 1998 
laboratoires, et un questionnaire concernant la formation et la certification des emballeurs dans les laboratoires. RÉSULTATS : Pendant la phase 1, 500 paquets arrivant au Laboratoire de lutte contre la maladie de la Colombie-Britannique ont été évalués. Tous les paquets sont arrivés intacts et 384 (76,8\%) d'entre eux dans un emballage extérieur rigide. Seuls $178(35,6 \%)$ des paquets contenaient un matériel absorbant. On savait que six échantillons contenaient le virus de l'immunodéficience humaine ou de l'hépatite $B$, tous étaient emballés adéquatement. Du reste, 11 (2,2\%) étaient considérés comme suremballés, 192 (38,4\%) comme emballés de façon acceptable, et $191(38,2 \%)$ emballés de façon inappropriée. Dans la phase 2, 138 paquets requis des laboratoires ont été évalués. Tous sont arrivés intacts et $132(95,7 \%)$ dans un emballage extérieur ferme. Quatre-vingt-seize $(69,6 \%)$ contenaient un matériel absorbant. Seuls six $(4,3 \%)$ ont été considérés comme emballés de façon inappropriée. Dans la phase 3, 171 laboratoires ont répondu au questionnaire. Cinquante-neuf réponses provenaient de petits laboratoires, 53 de laboratoires de taille intermédiaire et 23 de grands laboratoires. La plupart des laboratoires (55,4\%) s'appuyaient sur les ressources internes pour la formation des emballeurs. Seuls 26 établissements (15,3\%) n'avaient pas d'emballeurs certifiés, et 60,8\% avaient noté qu'ils disposaient d'une copie du règlement sur l'emballage au laboratoire. Les caractéristiques du laboratoire associées à la probabilité d'un suremballage comprenaient le nombre de technologistes $\left(x^{2}=5,72 ; p=0,058\right)$, le nombre d'échantillons préparés par les laboratoires $\left(x^{2}=8,46 ; p=0,015\right)$ et le fait d'être un laboratoire privé par opposition au fait d'être un laboratoire hospitalier (test bilatéral exact de Fisher 0,040).

CONCLUSIONS : Les laboratoires canadiens ont tendance à emballer les paquets de façon sûre et dans les limites acceptables des règlements, mais sans les suivre avec précision. La plupart des laboratoires possèdent des emballeurs expérimentés et certifiés. L'erreur la plus courante est l'utilisation d'un emballage extérieur non rigide. Les plus grands laboratoires ont tendance à suremballer les échantillons, avec pour conséquence une augmentation des coûts.

$P$ atient samples are often collected in locations distant from their final destination. The current trend of downsizing and centralization of laboratory services in Canada has led to an increased volume of patient samples sent from one site to another. The testing site might be down the road, across town, or in an entirely different city or province. Samples are transported for several reasons: initial testing in a central diagnostic laboratory, additional specialized testing of known infectious substances in a reference laboratory, or for research purposes in a research laboratory. Transportation directly influences safety, total cost and the turnaround time of laboratory testing.

Transport Canada is charged with reducing the health risk to the public from unsafe transporting practices. The Transportation of Dangerous Goods (TDG) regulations were significantly amended in 1994. One area of change was in packaging requirements for infectious substances. The regulations describe two packages called type $1 \mathrm{~A}$ and type $1 \mathrm{~B}$. The $1 \mathrm{~A}$ package is a standardized high containment package, while the $1 \mathrm{~B}$ package has less stringent design and labelling specifications $(1,2)$. The choice to use $1 \mathrm{~A}$ or $1 \mathrm{~B}$ in part depends on the risk group classification of each known infectious substance in the package. Organism risk groups were first introduced by the World Health Organization (WHO) and adopted by Health Canada for their publication, Laboratory Biosafety Guidelines (3). Transport Canada used these same risk group classification criteria and organism examples in the current TDG Regulations. Whether the package travels by air or ground and whether the sample is a culture or specimen may also influence the packaging decision. A third package option is alluded to in the regulations (Part 7.21); this package allows the sender greater choice in packaging but less protection from legal action should an accident occur $(1,4,5)$.

It is important to determine the current understanding and compliance with the Canadian regulatory requirements in transporting samples. Because the majority of samples being transported are for initial diagnostic testing or to confirm the presence of risk group 2 infectious substances, we conducted an anonymous external quality assessment to determine the degree of compliance by clinical laboratories for the packaging and transporting of partially controlled infectious substances.

\section{MATERIALS AND METHODS}

Phase 1: With the support and cooperation of the British Columbia Centre of Disease Control (BCCDC, Vancouver, British Columbia), routine sample packages arriving daily were examined. BCCDC is a provincial reference laboratory and receives human, animal, food and water samples from health units, laboratories and environmental centres. A total of 500 packages were observed over eight consecutive days. Each package was described and recorded as per the following parameters:

outer package - intact, firm, size $10 \mathrm{~cm}$ or greater, shipping document attached;

external safety marks and labelling present;

inner package - watertight primary container, watertight secondary container and absorbent material present; and

package type - most consistent with type 1A, type $1 \mathrm{~B}$ or the third packaging option 7.21 (Table 1).

Phase 2: Canadian laboratories participating in the Clinical Microbiology Proficiency Testing (CMPT) clinical bacteriology program were contacted for their approval to participate in this study. Laboratories from all provinces and territories agreed to participate. CMPT laboratories are located in all provinces except Manitoba, Ontario and Quebec.

An information letter was sent to all laboratories, followed by a written request to participate. Participants were randomly selected to submit either a live culture of Escherichia coli or a serum sample for serology testing. Serum for human immunodeficiency virus (HIV), hepatitis B and risk group 3 organisms were specifically excluded. Laboratories that had not responded after two weeks were sent a further request by facsimile to maximize the participation.

Satellite laboratories or sites that would normally forward 


\section{TABLE 1}

Glossary of terms used in study of packaging used for transport of biological samples

Inner package: A watertight primary container, a watertight secondary container and enough absorbent to contain the contents of the primary container should a leak occur.

Type 1A: An inner package as described above contained within a standardized outer package, with appropriate safety marks (TC 125-1A and name or registered symbol of person making the mark) and a shipper's declaration form. Package must comply with established rigorous criteria for size and durability.

Close to 1A: A package resembling 1A, complete with shipper's declaration form, but one component is either missing or incorrect.

Type 1B: An inner package as described above contained within a firm outer package, with appropriate safety marks (TC 125-1B and name or registered symbol of person making the mark). Less rigorous package criteria apply.

Close to 1B: A package resembling 1B, but one component is either missing or incorrect.

7.21: A watertight primary container and a watertight secondary container all within a firm outer package.

Inconsistent: $A$ package that does not sufficiently meet the requirements of the $1 \mathrm{~A}, 1 \mathrm{~B}$ or the third option packaging type described in the Transport of Dangerous Goods regulations.

Risk group 1: Organisms unlikely to cause disease in a healthy population (ubiquitous in nature) and that are not regulated.

Risk group 2: Organisms that can cause disease, but that are unlikely to be a serious hazard to the community (applies to most organisms in a diagnostic laboratory, including those in this study).

Risk group 3: Organisms causing serious disease that are not usually spread by casual contact or for which treatment is available (eg, Mycobacterium tuberculosis).

Risk group 4: Organisms causing serious disease, readily transmitted and often untreatable (there are only viruses in this category and are not dealt with in the routine diagnostic laboratories).

all samples to another laboratory for final packaging were excluded from phase 2 but included in phase 3. Packages from the individual laboratories were examined using identical parameters to the phase 1 group.

Phase 3: A questionnaire was mailed out to each CMPT participant. Requested information included the following:

demographics - volume of testing, number of staff, number of send-outs and where the majority of samples are sent;

TDG training - number of sample packers and who trained them;

TDG certification - who certified them, how often re-certification has taken place; and

TDG resources - type of TDG reference material available to the laboratory

The authors were unaware of other published studies designed to examine performance in regulatory compliance addressing transport of infectious materials. Therefore, the
TABLE 2

Comparison between phase 1 and phase 2 packages

\begin{tabular}{lcc}
\hline & $\begin{array}{c}\text { Phase 1 not } \\
\text { requested } \\
\text { packages } \\
\mathbf{n = 5 0 0}\end{array}$ & $\begin{array}{c}\text { Phase 2 } \\
\text { requested } \\
\text { packages } \\
\mathbf{n = 1 3 8}\end{array}$ \\
\hline Outer package & $500(100 \%)$ & $138(100 \%)$ \\
Intact & $384(76.8 \%)$ & $132(95.7 \%)$ \\
Firm & $368(73.6 \%)$ & $86(62.3 \%)$ \\
103 cm or greater & $219(43.8 \%)$ & $7(5.1 \%)$ \\
Leakproof & $26(5.2 \%)$ & $22(15.9 \%)$ \\
Shipper's declaration & $92(18.4 \%)$ & $67(48.6 \%)$ \\
Hazard sticker & $61(12.2 \%)$ & $50(36.2 \%)$ \\
Package designation & $71(14.2 \%)$ & $56(40.6 \%)$ \\
Name/symbol & & $137(99.3 \%)$ \\
Inner package & $495(99.0 \%)$ & $135(97.8 \%)$ \\
Watertight primary & $423(84.6 \%)$ & $96(69.6 \%)$ \\
Watertight secondary & $178(35.6 \%)$ & $\mathrm{NA}$ \\
Absorbent present & $84(42.0 \%)^{*}$ & $12(8.7 \%)$ \\
Multiple tubes secure & & $7(5.1 \%)$ \\
TC package types & $7(1.4 \%)$ & $15(10.9 \%)$ \\
1A & $10(2.0 \%)$ & $66(47.8 \%)$ \\
Close to 1A & $12(2.4 \%)$ & $32(23.2 \%)$ \\
1B & $143(28.6 \%)$ & \\
Close to 1B & $137(27.4 \%)$ & \\
7.21 & $191(38.2 \%)^{+}$ & \\
Inconsistent with Transport of & & \\
Dangerous Goods package & & \\
requirements & & \\
Known to contain human & $(1.2 \%)$ & \\
hepatitis B & & \\
\hline
\end{tabular}

${ }^{*} 42.0 \%$ of 200 packages sent containing multiple samples; ${ }^{\dagger} 70$ of these packages contained water samples for environmental testing or other nonbiological samples. When corrected for these samples, the effective value is $24.2 \%$ inconsistent. NA Not applicable

questionnaire was designed to be consistent with others sent from the CMPT program addressing laboratory characteristics with performance. It was pretested for content, clarity, simplicity and neutrality. All questionnaire data entries were manually checked for entry errors.

Relationships between results of phase 2 performance and phase 3 responses were examined. Results were tabulated in Microsoft Access (Washington). Analyses was performed using Microsoft Excel (Washington), EPI Info (Centers for Disease Control and Prevention, Georgia) and Kwikstat (TexaSoft, Texas) software.

For purpose of statistical analysis, results were aggregated into three categories, overpackaged (1A or 1A-like), acceptably packaged (1B or 1B-like or third option) and inadequately packaged (nonfirm outer package). Statistical examination was performed using ${ }^{2}$ analysis.

\section{RESULTS}

Phase 1: A total of 500 packages transported to BCCDC from hospital laboratories, private laboratories, health units, clinics and environmental testing sites were examined (Table 2). All 
TABLE 3

Phase 3 questionnaire results from participants in the Clinical Microbiology Proficiency Testing (CMPT) clinical bacteriology program

Number of specimens or samples received last year (ie, in the previous $\mathbf{1 2}$ months)

\begin{tabular}{|c|c|c|c|c|c|}
\hline$<1000$ & $1001-10,000$ & $10,001-50,000$ & $50,001-100,000$ & $\begin{array}{c}100,001- \\
500,000\end{array}$ & 750,000 \\
\hline 15 & 43 & 33 & 21 & 37 & 14 \\
\hline \multicolumn{6}{|c|}{ Number of specimens or samples sent out last year (ie, in the previous 12 months) } \\
\hline$<100$ & $101-500$ & $501-1,000$ & $1001-5000$ & $5001-10,000$ & $>10,000$ \\
\hline 5 & 8 & 7 & 58 & 52 & 36 \\
\hline
\end{tabular}

Majority of specimens or samples are sent to

Central processing Provincial laboratory or another Special research

laboratory reference laboratory laboratory $\quad$ Other

$250143 \quad 0 \quad 0$

Total number of personnel (including technologists and assistants) employed by laboratory

\begin{tabular}{lcccc}
$1-5$ & $6-10$ & $11-25$ & $26-50$ & $51-100$ \\
\hline 55 & 28 & 36 & 25 & 15 \\
Number of specimen packers employed by laboratory & & & \\
None & $1-5$ & $6-10$ & $>10$ & \\
\hline 2 & 106 & 21 & 28 &
\end{tabular}

Training in transport requirements for Canada was/were done by (all that apply)

Previously trained in-

house packer

62

In-house transport specialist

Private company

University/community

$\begin{array}{llllll}62 & 44 & 44 & 8 & 33\end{array}$

Certified packers

\begin{tabular}{|c|c|c|c|c|c|c|}
\hline Not certified & $\begin{array}{c}\text { Not certified but aware of certification } \\
\text { program }\end{array}$ & Certified & Recertified & \multicolumn{3}{|c|}{ Frequency of recertification } \\
\hline & & & & 1 year & 2 year & 3 year \\
\hline 26 & 6 & 144 & 144 & 7 & 23 & 71 \\
\hline \multicolumn{7}{|c|}{ Packers were certified by (all that apply): } \\
\hline $\begin{array}{l}\text { No formal certification } \\
\text { after training }\end{array}$ & $\begin{array}{l}\text { Certification included } \\
\text { in the course }\end{array}$ & $\begin{array}{c}\text { In-house } \\
\text { transport specialist }\end{array}$ & $\begin{array}{l}\text { Head of } \\
\text { the department }\end{array}$ & Other & & \\
\hline 14 & 72 & 33 & 27 & 9 & & \\
\hline \multicolumn{7}{|c|}{ Transportation of Dangerous Goods resources available in the laboratory (all that apply) } \\
\hline $\begin{array}{l}\text { Formal copy } \\
\text { of regulations }\end{array}$ & $\begin{array}{l}\text { Notes from } \\
\text { training course }\end{array}$ & $\begin{array}{c}\text { Journal articles } \\
\text { describing regulations }\end{array}$ & Other & None available & & \\
\hline 104 & 70 & 19 & 28 & 3 & & \\
\hline
\end{tabular}

packages had intact outer packaging; however, only 384 $(76.8 \%)$ were made of a firm outer packaging consisting of a minimum of fibreboard. The remaining outer packages were envelopes either with or without bubble wrap. It was noted that only one package had actually leaked. Most packages contained samples that should have been sent in 1B containers; however, six samples were noted to contain serum for HIV or hepatitis B. All six were packaged and marked consistent with complete and proper 1A packaging.

Phase 2: Of the 185 samples requested from CMPT participants, 141 packages were received and described. Of the 44 laboratories that did not participate, 33 were satellite laboratories that refer to a single central testing site. Thus, the true participation rate by laboratories that routinely transport materials was 141 of 152 (92.8\%). Three packages were excluded because the outer package was removed before descriptions could be made (Table 2). All outer packaging was intact. In this group, only six (4.3\%) used envelope packaging as op- posed to $116(23.2 \%)$ in phase 1 . This difference was statistically significant $\left({ }^{2}=23.65 ; P=0.0000012\right)$. When the 70 environmental samples were excluded from phase one, the number of sample envelopes packaged dropped to 46 (10.7\%), still a significant difference, albeit to a much lesser degree $\left({ }^{2}=23.65 ; \mathrm{P}=0.012\right)$. Although all samples can be properly packaged and sent in 1A packaging, for the samples requested 1A packaging was not necessary, had increased cost and potentially caused increased handler anxiety, and as such was deemed overpackaging. By this definition, 19 (13.8\%) of packages in phase 2 were overpackaged as opposed to $11(2.5 \%)$ in phase $1\left({ }^{2}=29.77 ; \mathrm{P}=0.0000001\right)$.

Phase 3: Of the 185 questionnaires requested from CMPT participants, 171 (92.4\%) were returned and tabulated. Some respondents chose not to answer all questions (Table 3).

of the laboratories participating in the study, the annual number of samples received ranged broadly as did the number of samples requiring packaging for transport. The most com- 
TABLE 4

Reported number of employees versus performance

\begin{tabular}{lcccc}
\hline $\begin{array}{c}\text { Number of } \\
\text { employees }\end{array}$ & $\begin{array}{c}\text { Over- } \\
\text { packaged }\end{array}$ & $\begin{array}{c}\text { Acceptable } \\
\text { package }\end{array}$ & $\begin{array}{c}\text { Under- } \\
\text { packaged }\end{array}$ & Total \\
\hline $1-10$ & 4 & 54 & 1 & 59 \\
$11-50$ & 8 & 41 & 4 & 53 \\
$>51$ & 8 & 16 & 1 & 25 \\
\hline
\end{tabular}

$\chi^{2}=5.72 ;$ Degrees of freedom $=2, P=0.058$

TABLE 5

Reported number of samples processed in the laboratory versus performance

\begin{tabular}{lcccc}
\hline $\begin{array}{l}\text { Number } \\
\text { of samples }\end{array}$ & $\begin{array}{c}\text { Over- } \\
\text { packaged }\end{array}$ & $\begin{array}{c}\text { Acceptable } \\
\text { package }\end{array}$ & $\begin{array}{c}\text { Under- } \\
\text { packaged }\end{array}$ & Total \\
\hline$<1000-10,000$ & 2 & 45 & 1 & 48 \\
$10,001-100,000$ & 5 & 35 & 3 & 43 \\
$100,001->500,000$ & 11 & 32 & 2 & 45 \\
\hline
\end{tabular}

$\chi^{2}=8.46 ;$ Degrees of freedom $=2 ; P=0.015$

mon destinations for samples were the provincial laboratories. Most laboratories $(106,67.5 \%)$ designated one to five persons as specimen packers. Most laboratories (106, 55.5\%) relied on in-house personnel to train other personnel. Only 15 to $32(9.2 \%$ to $18.2 \%)$ laboratories, depending on question response, reported that they did not have certified packers. Only three (1.6\%) laboratories reported that they did not have access to information concerning transport regulations.

Relationships between laboratory characteristics as reported in phase 3 and performance in phase 2 were sought. No significant relationships were noted between performance and geographic region of the laboratory, whether technologists were certified or whether laboratories had access to a formal copy of regulations. Several relationships were noted that either were statistically significant or almost significant (Tables 4-6). Combined the results presented in these Tables suggest that large laboratories (often private laboratories), measured either by number of technologists or number of samples processed, were more likely to overpackage compared with other laboratories.

\section{DISCUSSION}

The observations of this paper demonstrate that most laboratories are aware of transporting requirements and are capable of providing safe packages but are less likely to package in a manner fully compliant with regulations. This was seen to a greater extent in phase 1 , where senders were not informed that their packaging would be examined versus phase 2 where senders were notified. Several factors may account for this difference. In phase 2, each package was sent from a separate laboratory, whereas in phase 1 there was no such restriction, Thus, part of the difference observed may be that some laboratories in phase 1 sent more than one package. In addition, the group of senders was different in the two phases. In phase 1, $233(46.5 \%)$ of the senders were hospital laboratories, with the balance of packages coming from clinics and private laboratories. In phase 2, hospital laboratories constituted 109 (88.6\%)
TABLE 6

Reported number of laboratory type versus performance

\begin{tabular}{lcccc}
\hline Training & $\begin{array}{c}\text { Over- } \\
\text { packaged }\end{array}$ & $\begin{array}{c}\text { Acceptable } \\
\text { package }\end{array}$ & $\begin{array}{c}\text { Under- } \\
\text { packaged }\end{array}$ & Total \\
\hline Hospital & 10 & 110 & 5 & 125 \\
Private & 2 & 8 & 1 & 11 \\
\hline
\end{tabular}

Fisher two-tailed test $=0.040$

of the group. In phase 1, laboratories were more likely to send samples in envelope packaging. Unfortunately, facilities sending samples in envelopes were not contacted by the study group. Thus, no additional information was available to ascertain other characteristics in common.

The three factors associated with overpackaging (number of samples, number of technologists and being a private laboratory) are probably related. It is difficult to ascertain to what extent these laboratories use 1A packages regularly or how much of the use was influenced by 'faking good' bias. In the process of wanting to be seen to be correct, the laboratories may have overcompensated, resulting in overpackaging. While this may have played a role, had this been a major factor, it would have been more likely to have been a more widespread effect. Other studies on the impact of blind versus open proficiency challenges have demonstrated improved but not significant differences in performance (6). Routine overpackaging can increase the overall cost of sample transportation. The packages are costly themselves and as such are often returned for reuse, resulting in transporting charges in both directions.

When preparing a sample for transport, the sender (consignor) must first assess the risk of the package contents. A sample for initial diagnostic testing has a low risk of containing a fully controlled infectious substance and, as such, does not require the standardized high containment package. If the package is known to contain a pathogen, the risk level must be considered when choosing an appropriate package $(1,4,5)$. Phase 2 of this study focused on the majority of samples transported, which consist of diagnostic specimens and risk group 2 organisms. Thus, the expected package was a type $1 \mathrm{~B}$ package, though the regulations do allow for variation under the 7.21 guideline. We did not accept a nonfirm outer package as meeting the intent of the 7.21 guideline.

In phase 1 , packages containing water samples were examined. Whether these samples require $1 \mathrm{~B}$ packaging is debatable. While water samples may indeed carry bacteria, the concentration is exceedingly low. On the other hand, the consequence of a leaked sample raises the perception of danger by package handlers regardless of whether microorganisms are present. Because a complete 1B package with waterproofing, and absorbent and firm packaging would reduce the potential for leakage, we conditionally included them in the analysis.

of the 638 packages examined, it is important to appreciate that $122(19.1 \%)$ would have been considered not only inconsistent with current regulation, but also potentially unsafe because they were transported in packages that were not firm. of the 122 packages, one $(0.8 \%)$ actually leaked outside the pack- 
age, resulting in follow-up action including decontamination and containment procedures.

When we compared the reported transport training and certification (questionnaire answers) with the actual performance, no trends or associations were noted. This may have been due to the size of the groups being examined or may reflect the quality of training and certification. Although Transport Canada provides guidelines on training, there is no standardization for either training or the requirements for certification, other than that the employers needs to be satisfied that the employee is knowledgeable. Four of the six laboratories that sent improperly packaged samples stated that they had certified packers.

There are few published studies looking at transportation of packages containing infectious substances. In a four-year study, Garner and Masterton (7) demonstrated that unsafe packages are rare but that compliance with regulation increased with awareness.

Samples that are transported in Canada fall within Transport Canada's guidelines. In 1994, changes in regulation resulted in a code that would allow for simple, safe transport of samples for domestic transport in Canada. As opposed to international transport, most samples and isolates can be trans-

\section{REFERENCES}

1. Transportation of Dangerous Goods Act and Regulations. Registration SDR 85-77. Amendment SOR94264. Ottawa: Canadian Publishing Centre, Ministry of Supply and Services Canada, 1994.

2. National Standard of Canada. Packaging of infectious substances and diagnostic specimens. Canadian Standards Board CAN/CGSB-43,125-M90. Ottawa: Ministry of Supply and Services Canada, 1990.

3. Laboratory Centre for Disease Control, Health Protection Branch, Health Canada. Laboratory Biosafety Guidelines. Ottawa: Ministry of Supply and Services Canada, 1996. ported in inexpensive, firm boxes without a shipper's declaration or biohazard label. Requirements for the outside of the package are that it be marked with the type of packaging (TC-125-1B) and the shipper's identification. Only for special organisms of a higher risk nature (special groups within risk group 2, most risk group 3 and all risk group 4) require full packaging and labelling (1-5). This is not the case for international transport, making domestic transport simpler and less expensive.

\section{CONCLUSIONS}

Despite trained packers being available, most diagnostic samples and infectious substances were transported in a manner that is safe but not compliant with current TDG regulations. Packages are often both overpackaged and underpackaged. More effective education specific to transportation of infectious substances is needed for all sites shipping samples.

ACKNOWLEDGEMENTS: We acknowledge the assistance and support of Transport Canada, the British Columbia Provincial Laboratory, and the staff of the Clinical Microbiology Proficiency Testing Program. Without their assistance, this study could not have been completed.

4. Porter-Cathcart N, Paquette M. New regulations for infectious substances. Dangerous Goods Newsl 1994;14:6-11.

5. Noble MA. Understanding transport of infectious materials inside Canada - 1994. CACMID Newsletter 1994;9:8-12.

6. Kumasaka K, Kawano K, Yamaguchi K, et al. Review of the Tokyo metropolitan external quality assessment program for clinical microbiology. In: Ohba Y, Kanno T, Okabe H, et al, eds. Quality Control in the Clinical Laboratory '95. Tokyo: Excepta Medica, 1995:375-81.

7. Garner P, Masterton RG. Specimen transport audit. J Clin Pathol 1990;43:712-3. 


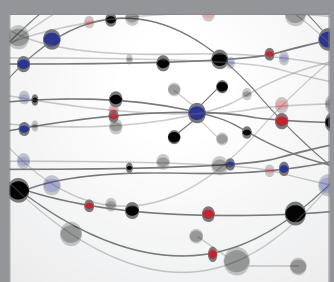

The Scientific World Journal
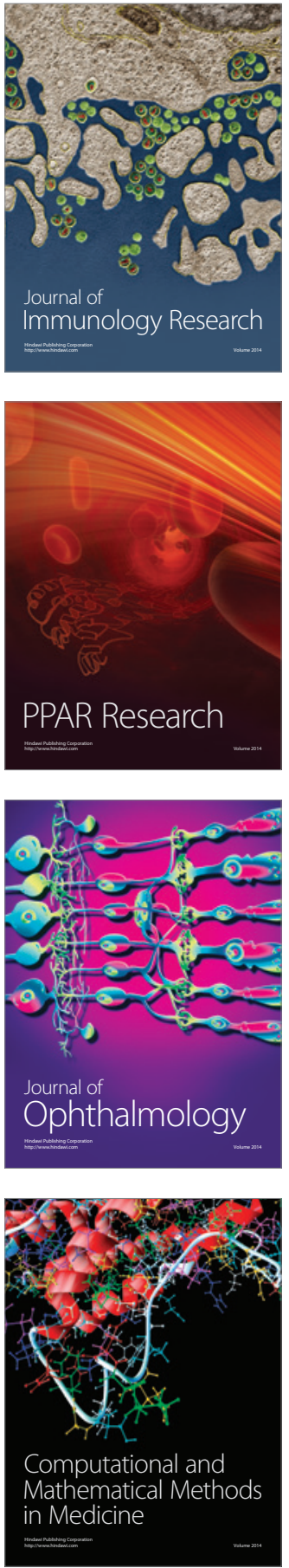

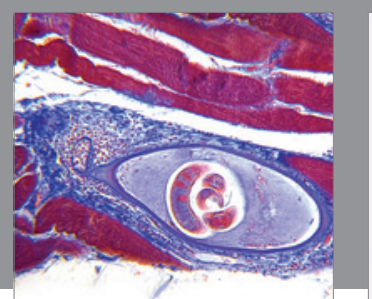

Gastroenterology Research and Practice

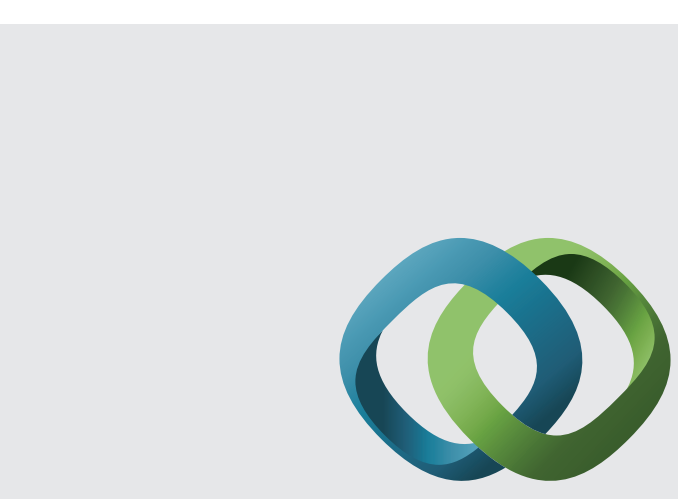

\section{Hindawi}

Submit your manuscripts at

http://www.hindawi.com
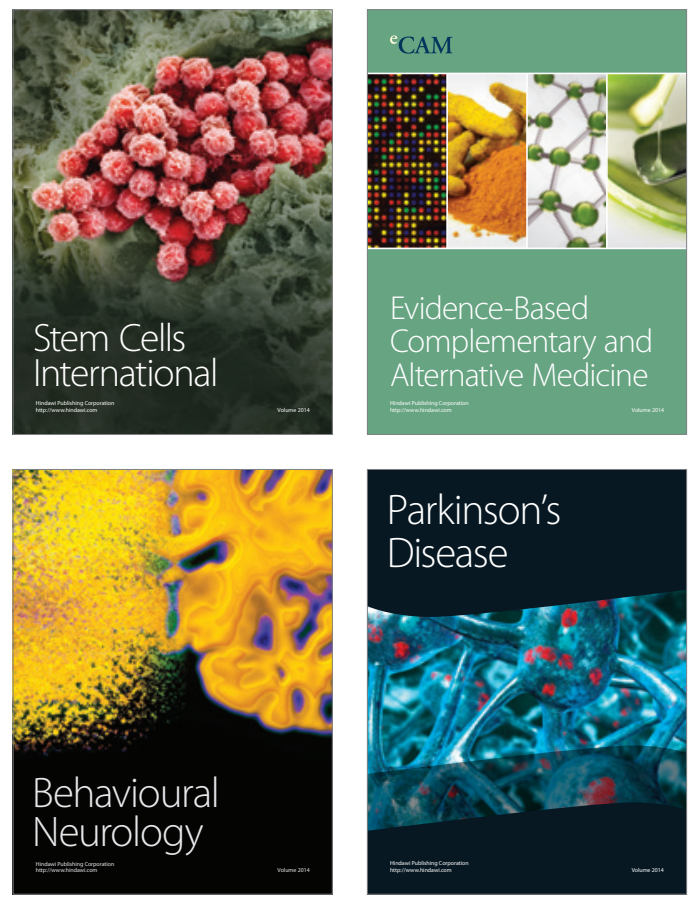
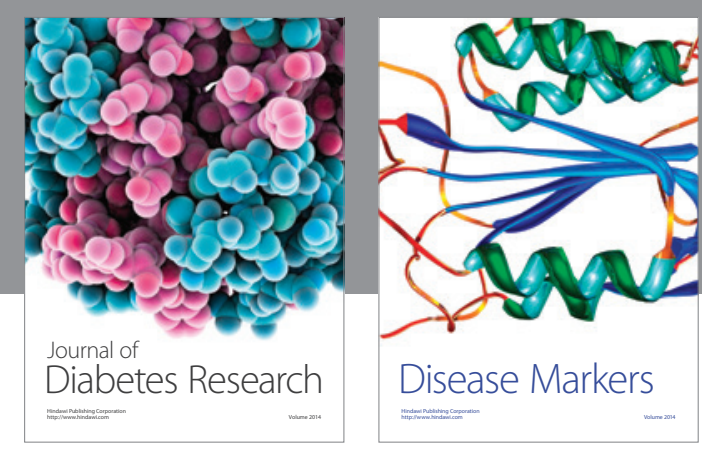

Disease Markers
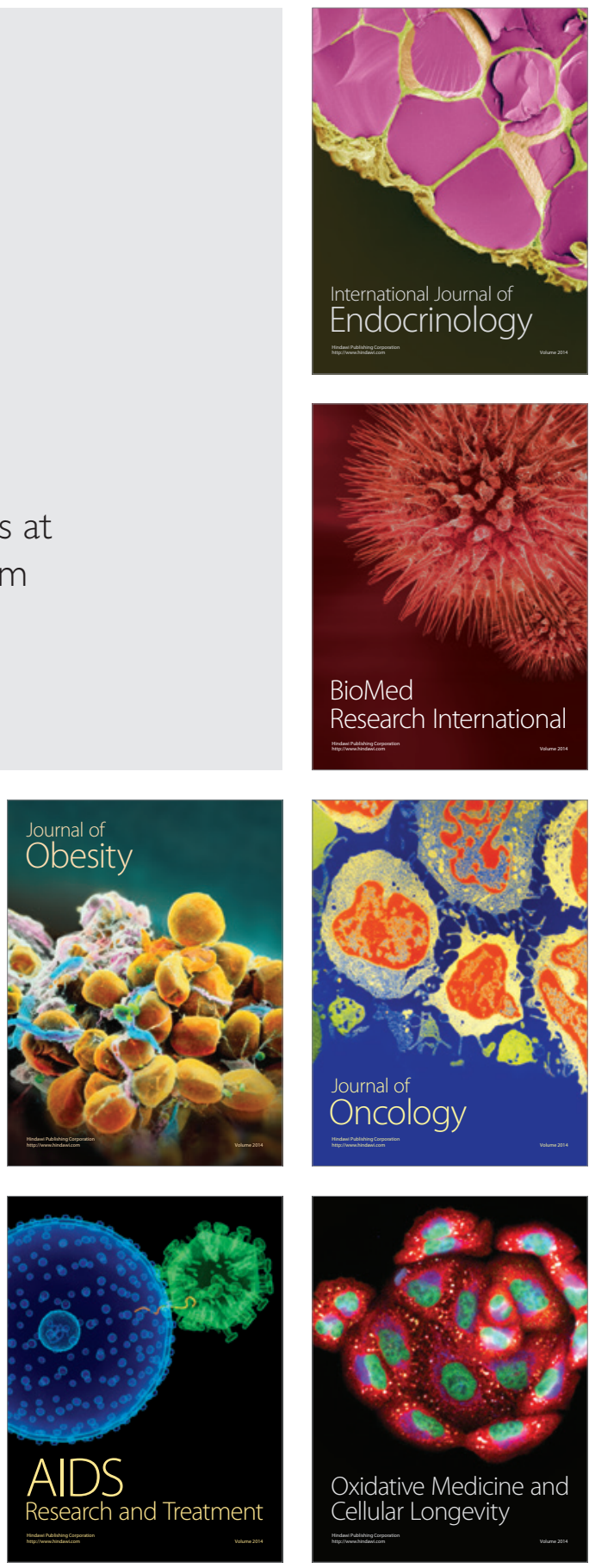